Bangl. J. Vet. Med. (2011). 9(1): 43 - 52

\title{
EVALUATION OF THE EFFECTIVENESS OF COMMERCIALLY AVAILABLE DISINFECTANTS AGAINST SALMONELLAE ISOLATED FROM INTERNAL ORGANS OF DEAD CHICKENS
}

\author{
N.A. Rumi, M.M. Rahman, M.R. Akter, M. Fakhruzzaman and M.K. Hossain \\ Department of Microbiology, Faculty of Veterinary and Animal Science, Hajee Mohammad Danesh Science and \\ Technology University, Dinajpur-5200, Bangladesh
}

\begin{abstract}
The effectiveness of commercially available disinfectants was evaluated against Salmonellae isolated from different internal organs of 52 numbers of dead layer chickens in the district of Dinajpur during the period from July 2009 to June 2010. Bacterio-biochemical methods were used to isolate and identify the Salmonella organisms from 154 samples of liver, spleen, heart and lungs of birds, of which 36 (23.38\%) samples had Salmonella infection. Organ-wise prevalence of Salmonella infection showed highest prevalence in liver ( 34.62\%), followed by spleen (23.087\%), heart (20.00\%) and lowest in lungs (4.00\%). Effectiveness of disinfectants was tested at different concentration on Salmonella culture on SS agar media and measured by zone of inhibition incubated for 24 hours. Highest average zone of inhibition was recorded with Desinkap ${ }^{\circledR}$ $(12.50 \pm 2.08)$, followed by GPC $(8) \mathrm{TM}^{\circledR}(11.33 \pm 1.53)$, and more or less similar patterns with TH ${ }^{4 \circledast}(10.50 \pm 0.71)$, Virocid ${ }^{\circledR}(10.50 \pm 0.71)$ and Lysol ${ }^{\circledR}(10.00 \pm 0.00)$. It may be concluded from these results that Desinkap ${ }^{\circledR}$ is the most effective disinfectant against Salmonellae as it contains multiple ingredients.
\end{abstract}

Key words: Disinfectants, salmonella, isolates, effectiveness, chickens

\section{INTRODUCTION}

The importance of salmonellosis in poultry industry has increased to be growing concern day by day throughout the world during the last decades. The etiologic agents are responsible for various pathogenic processes in man and animals including poultry (Freeman, 1985). With the great expansion of poultry rearing and farming, Fowl Typhoid caused by Salmonella gallinarum is the most devastating disease in Bangladesh (Begum et al., 1993 and Hoque et al., 1992).The disease can be controlled by maintaining of high level of biosecurity, routine serological test and screening of birds positive to Salmonella. The epidemiology of Fowl typhoid and Pullorum disease in poultry, particularly with regard to transmission from one generation to the next is known to be associated with infected eggs (Hofstad et al., 1992). Although more than 2300 serotypes of Salmonella have been identified, only $10 \%$ of these have been isolated from poultry (Gast, 1997). Salmonella gallinarum can produce lesions in chicks, which are indistinguishable from those associated with Pullorum disease. With great expansion of the poultry rearing and farming, Pullorum disease and Fowl typhoid have become wide spread problem in Bangladesh like other area of the world (Sarker, 1976 and Rahman et al., 1979). Heavy economic losses occur both in broiler and layer flock due to morbidity, mortality, reduced production and poor chick quality. Mortality may vary from negligible to higher (10\% to $80 \%$ ) in severe outbreaks (Kumar and Kaushi, 1988; Kaura et al., 1990; Kleven and Yoder, 1998). The poultry industry is intensive and consistently applies an all-in, all-out system with the aim of minimizing infection pressure and targeting specific organisms like Salmonella. Therefore, disinfecting during production break is a routine part of the management of poultry houses. Several chemical disinfectants are commercially available in the local markets but their efficacy have not been evaluated in Bangladesh. This paper describes the comparative effectiveness of commercially available disinfectants against Salmonella isolates. 


\section{N.A. Rumi and others}

\section{MATERIALS AND METHODS}

The study was conducted from July 2009 to June 2010 in 154 field samples comprising liver, spleen, heart \& lungs of dead layer chickens aseptically collected from Basherhat, Gobindapur and Mohabolipur of Dinajpur sadar upazila under the district of Dinajpur.

\section{Culture Media}

Different solid bacteriological culture media used in this study were Nutrient agar (NA) (Himedia,India), Salmonella-Shigella (S-S) agar (Himedia, India), Brilliant green agar (BGA) ( Himedia, India), Mac Conkey agar (Himedia, India), Eosine methylene blue (EMB) agar ( Himedia, India) and Simmons citrate agar (Himedia, India) media. The liquid culture media were Nutrient broth (NB) ( Himedia, India) and Bacto selenite broth (Himedia, India) and biochemical media were Sugar media (dextrose, maltose, lactose, mannitol and sucrose),Tripple sugar iron (TSI) agar, Motility Indole Urea (MIU). Other solutions for conducting biochemical tests were Methyl Red, Voges Proskauer solutions.

\section{Antisera}

Salmonella Polyvalent 'O' (A-I) antisera manufactured by Statens Serum Institute, Copenhagen, Denmark, was used for the sero-grouping of Salmonella isolates.

The entire study is divided into two steps. The first step includes the isolation of the bacteria from internal organ of dead birds and identification of Salmonella by cultural, morphological and biochemical characteristics. The second step is evaluating the effectiveness of commercially available disinfectants against Salmonella isolates.

\section{Collection of samples}

Liver, spleen, heart, and lung samples were collected from dead birds of study areas and transferred immediately into a Petridish. The Petridish containing samples were then immediately brought to the Microbiology Laboratory, Department of Microbiology, Hajee Mohammad Danesh Science and Technology University, Dinajpur.

\section{Cultivation and isolation of Salmonella}

The samples were inoculated into Nutrient agar media and incubated at $37^{\circ} \mathrm{C}$ for 24 hours aerobically in bacteriological incubator. The incubated tubes were then examined for growth of bacteria. Smears were prepared from each of the petridishes and the smears were fixed. The fixed smears were stained with Gram's Method of staining and examined under microscope at $100 \mathrm{X}$ magnifications using immersion oil. In presence of Gram negative rods in the smears, the materials from the petridishes corresponding to the smears were streaked into Mac Conkey agar, Salmonella-Shigella agar and Brilliant green agar separately. The plates were then incubated at $37^{\circ} \mathrm{C}$ for 24 hours and the plates containing characteristic colonies of Salmonella were selected. Gram's staining tests are performed to identify the plates containing Salmonella accurately. Sub-culturing in SalmonellaShigella (SS) agar was performed from the suspected plates containing Salmonella to obtain a pure culture. These pure isolates obtained in this way were used for further study.

\section{Morphological examination}

The representative Salmonellae isolates from SS agar were stained by Gram's stain (Marchant and Packer, 1967).

\section{Biochemical examination}

Isolated organisms with supporting growth characteristics of Salmonella on various media were maintained on Salmonella-Shigella (SS) and Brilliant green Agar (BGA) and were subjected to the different biochemical tests named sugar fermentation test, MR-VP reaction, TSI, MIU and Indole reaction ( Marchant and Packer, 1967).

\section{Sero-grouping of Salmonella}

Sero-grouping of Salmonella isolates was performed by slide agglutination test using specific polyvalent ' $\mathrm{O}$ ' (A-I) antisera. The test was performed according to the protocol of specific Statens Serum Institute, Copenhagen, Denmark (Buxton and Fraser, 1977). 


\section{Evaluation of the effectiveness of disinfectants}

\section{Preparing agar for petridishes}

Before the Petridishes were inoculated with Salmonella isolates, selective media (SS agar) was prepared to pour in the bottom of each dish. Approximately $15 \mathrm{ml}$ of agar solution was poured into the bottom of each of the petridishes.

\section{Growing Salmonella isolates into petridishes}

To grow the Salmonella, $1 \mathrm{ml}$ of nutrient broth was pipetted onto the $100 \%$ concentration of Salmonella and was mixed. After the Salmonella was mixed with the nutrient broth, $1 \mathrm{ml}$ of the mixture was removed and placed back into the original stock tube containing the nutrient broth. The mixture was then incubated for 24 hours at $37^{\circ} \mathrm{C}$. After the Salmonella was incubated for 24 hours, each dish was inoculated with $100 \mu$ of liquid Salmonella from the stock tube. After the Salmonella were placed on the plate, they were spread over the plate with a glass rod. The plates were then ready to have the disinfectants applied.

\section{Preparation of different concentration of disinfectants}

A total of five commercially available disinfectants were evaluated for their efficacy against Salmonella isolates. The disinfectants were made in three forms, one (01) according to the manufacturers recommendation, three (03) were higher and one (01) was lower than manufacturers recommendation.

Table 1. Different concentration of commercially available disinfectants for the evaluation of their effectiveness

\begin{tabular}{|c|c|c|c|c|c|}
\hline Disinfectants(Composition and & & $\begin{array}{l}\text { ed diff } \\
\text { of dis }\end{array}$ & $\begin{array}{l}\text { nt co } \\
\text { ecta }\end{array}$ & $\begin{array}{l}\text { ntrat } \\
\%)\end{array}$ & \\
\hline $\begin{array}{ll}\text { Desinkap }^{\circledR} \text { (Formaldehyde,Glutaraldehyde, } & \text { Glyoxal, } \\
\text { Benzylconium) (Lion Overseas Trading Company) } & \end{array}$ & 0.3 & $0.4^{*}$ & 0.5 & 0.6 & 0.7 \\
\hline GPC (8)TM ${ }^{\circledR}$ (Glutaraldehyde) (Renata Ltd.) & 0.4 & $0.5^{*}$ & 0.6 & 0.7 & 0.8 \\
\hline $\mathrm{TH}^{4}{ }^{\circledR}$ (Quaternary ammonium compounds) (Century Agro Ltd.) & 0.4 & $0.5^{*}$ & 0.6 & 0.7 & 0.8 \\
\hline $\begin{array}{l}\text { Virocid }{ }^{\circledR} \text { (Quaternary ammonium } \\
\text { compounds)(ACI Ltd.) }\end{array}$ & 0.5 & $0.6^{*}$ & 0.7 & 0.8 & 0.9 \\
\hline Lysol ${ }^{\circledR}$ (Tar acid) (Coventry Chemicals Ltd.) & 2.4 & $2.5^{*}$ & 2.6 & 2.7 & 2.8 \\
\hline
\end{tabular}

* Manufacturer's recommendation

\section{Measuring Zones of Inhibition}

After the 24-hour incubation time, the dishes were observed. The zones of inhibition were measured by measuring the diameter of the clear inhibition zone surrounding each disk with a ruler.

\section{Statistical analysis}

A statistical analysis was performed after collecting the zone of inhibition measurements. An ANOVA statistical analysis was performed for all the zone of inhibition measurements for 24 hours of incubation.

\section{RESULTS AND DISCUSSION Isolation of Salmonella spp}

Out of 154 samples 36 (23.38\%) were found to be positive to Salmonella. Among the positive samples, 17 (24.29 \%) were from Basherhat, 12 (22.22 \%) from Gobindapur and 7 (23.33\%) from Mohabolipur area of Dinajpur. The percentages of positive samples (liver, spleen, heart, lungs) from those areas were 24.29 \%, 22.22 $\%$ and $23.33 \%$ respectively and the average prevalence of Salmonella was $23.38 \%$ (Table 2) which was lower than the observation of Habib-ur-Rehman et al. (2004), Ahmed et al. (2008) might be due to difference in number of birds tested or due to various areas. In case of internal organs, Salmonella were detected from 18 samples of liver, 12 samples of spleen, 5 samples of heart and 1 sample of lung and the prevalence was $34.62 \%$, $23.08 \%, 20.00 \%$ and $4.00 \%$ respectively (Table 3). Habib-ur-Rehman et al. (2004) described $34.50 \%$ cultural prevalence of Salmonella infection in dead birds where $10.50 \%$ in liver and $10.50 \%$ in spleen while Lee et al. (2001) described $47.60 \%$ in liver. Ahmed et al. (2008) described the average cultural prevalence in the dead bird was $60.50 \%$ in which $64.00 \%$ cultural prevalence in the liver and $57.00 \%$ in the cloaca. Among the 52 samples 


\section{N.A. Rumi and others}

tested from liver, Salmonella could be isolated from 18 (34.62 \%) samples which were higher than the findings of Habib-ur-Rehman et al. (2004) and lower than Lee et al. (2001) and Ahmed et al. (2008). Among the 52 samples tested from spleen, Salmonella could be isolated from 12 (23.08 \%) samples which were higher than the findings of Habib-ur-Rehman et al. (2004). From the above findings it was revealed that liver was the rich source for Salmonella contamination other than the spleen, heart and lungs, which was in close agreement with Sujatha et al. (2003).

Table 2. Isolation of Salmonella from internal organs of 52 numbers of dead birds from the study areas of Dinajpur district

\begin{tabular}{|c|c|c|c|c|c|}
\hline Study area & $\begin{array}{c}\text { Sources of } \\
\text { samples }\end{array}$ & $\begin{array}{c}\text { No. of } \\
\text { sample tested }\end{array}$ & $\begin{array}{l}\text { No. of } \\
\text { positive } \\
\text { isolates }\end{array}$ & $\begin{array}{l}\text { Prevalence of } \\
\text { isolates (\%) }\end{array}$ & $\begin{array}{c}\text { Average } \\
\text { Prevalence of } \\
\text { isolates(\%) }\end{array}$ \\
\hline \multirow{4}{*}{ Basherhat } & Liver & 25 & 8 & \multirow{4}{*}{24.29} & \multirow{20}{*}{23.38} \\
\hline & Spleen & 25 & 6 & & \\
\hline & Heart & 10 & 2 & & \\
\hline & Lung & 10 & 1 & & \\
\hline \multirow[t]{2}{*}{ Sub total } & & 70 & 17 & \multirow{5}{*}{22.22} & \\
\hline & Liver & 17 & 6 & & \\
\hline \multirow{3}{*}{ Gobindapur } & Spleen & 17 & 4 & & \\
\hline & Heart & 10 & 2 & & \\
\hline & Lung & 10 & 0 & & \\
\hline \multirow[t]{2}{*}{ Sub total } & & 54 & 12 & \multirow{5}{*}{23.33} & \\
\hline & Liver & 10 & 4 & & \\
\hline \multirow{3}{*}{ Mohabolipur } & Spleen & 10 & 2 & & \\
\hline & Heart & 5 & 1 & & \\
\hline & Lung & 5 & 0 & & \\
\hline \multirow[t]{5}{*}{ Sub total } & & 30 & 7 & & \\
\hline & Liver & 52 & 18 & 34.62 & \\
\hline & Spleen & 52 & 12 & 23.08 & \\
\hline & Heart & 25 & 5 & 20.00 & \\
\hline & Lung & 25 & 1 & 4.00 & \\
\hline \multicolumn{2}{|c|}{$\begin{array}{l}\text { Total ( Liver, spleen, heart and } \\
\text { lungs) }\end{array}$} & 154 & 36 & 23.38 & \\
\hline
\end{tabular}

\section{Identification of Salmonella spp.}

All the isolates produced brick red coloration in Selenite broth and pinhead size to that of a lentil, raised, rounded or circular, smooth, glistening, opaque, colorless, transparent or translucent colonies on SS agar and pink red color colonies against a pinkish background when cultured on BGA and colorless, smooth, pale and transparent raised colonies on MacConkey agar media. These findings support the report of Freeman, (1985) and Jones et al., (1997). Salmonella isolates on nutrient agar, and other specific media revealed identical cultural characteristics which resemble the findings of Buxton and Fraser (1977). All the isolated Salmonellae revealed Gram-negative, pink coloured, short plump rod shaped, single and paired arrangement in Gram's staining technique which were identical to earlier studies of Buxton and Fraser (1977) and Freeman (1985). In biochemical tests all the isolates were positive to MR, TSI tests and negative to VP and Indole tests. All the isolates were negative to MIU media. This study correlates with the study of Pomeroy and Nagaraja (1991); and OIE (2000). Nonmotile organisms were considered to be either S. pullorum or S. gallinarum. All Salmonella isolates were unable to ferment lactose, sucrose, although dextrose, maltose and mannitol were fermented. This result is in agreement with the findings of Freeman (1985) and Jones et al. (1997). 


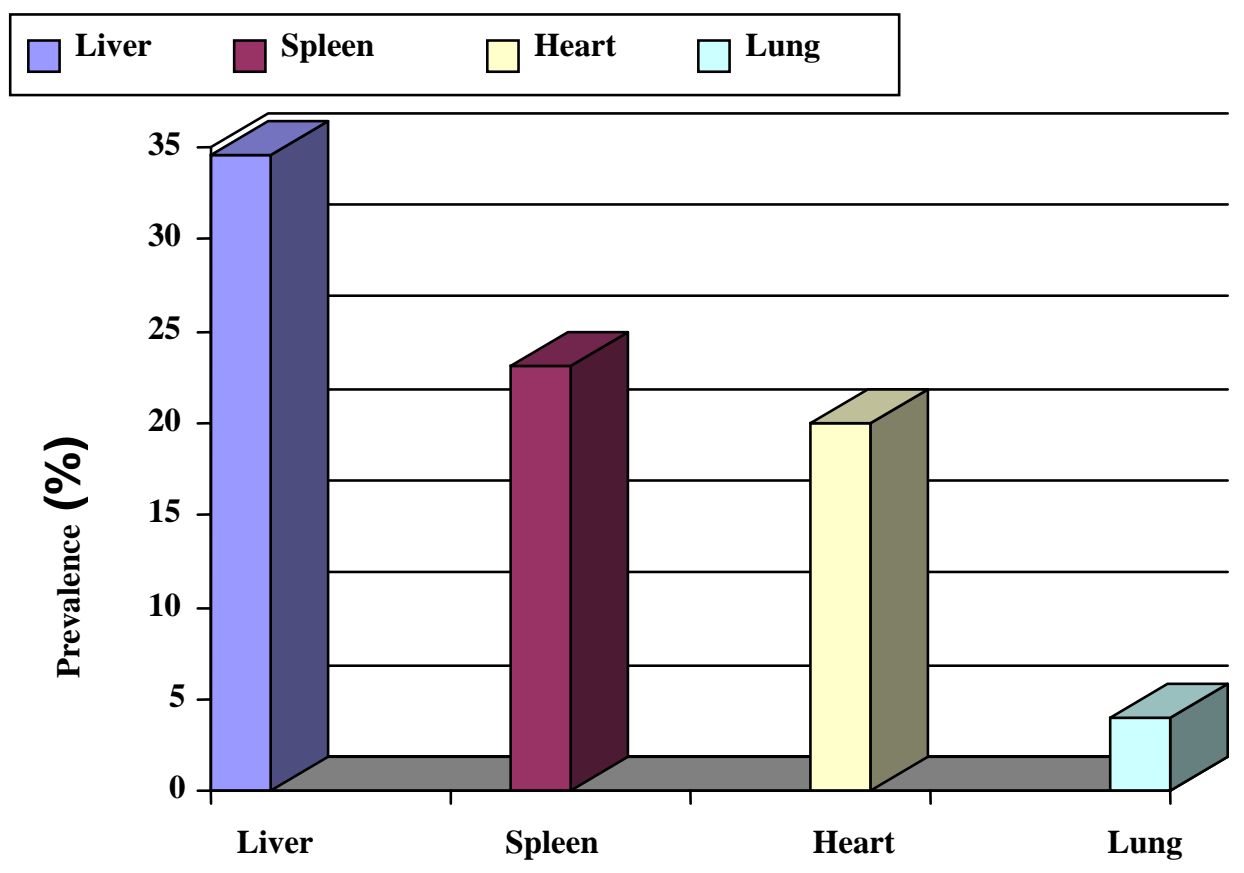

\section{Sources of samples}

Fig. 1. Prevalence of Salmonella isolated from internal organs of dead birds

\section{Evaluation of disinfectants against Salmonella isolates}

The effectiveness of the disinfectants in preventing the growth of Salmonella isolates was tested in the selective media such as SS agar. Among the disinfectants Desinkap ${ }^{\circledR}$ was found most effective of all the disinfectants in preventing the growth of Salmonella isolates as measured by zone of inhibition after being incubated for 24 hours (Table 4). GPC (8) TM ${ }^{\circledR}$ was found to be more effective than Virocid ${ }^{\circledR}$ and $\mathrm{TH}^{4 \circledast}$, but not more effective than Desinkap ${ }^{\circledR}$ but the result was not statistically significant ( $\left.>>0.05\right)$. These results support the report of Marin et al. (2009). TH ${ }^{4}{ }^{\circledR}$ and Virocid ${ }^{\circledR}$ were less effective than Desinkap ${ }^{\circledR}$ (Table 4). Lysol ${ }^{\circledR}$ was found less effective than other four disinfectants (Table 4). 


\section{N.A. Rumi and others}

Table 4. Evaluation of the effectiveness of commercially available disinfectant against Salmonella isolates in different concentration

\begin{tabular}{|c|c|c|c|}
\hline Name of the disinfectant & Concentration (\%) & $\begin{array}{l}\text { Time } \\
\text { (hour) }\end{array}$ & $\begin{array}{l}\text { Measuring Zones of Inhibition } \\
(\mathrm{mm})\end{array}$ \\
\hline \multirow{5}{*}{ Desinkap $^{(B)}$} & 0.3 & 24 & - \\
\hline & $0.4^{*}$ & 24 & 10 \\
\hline & 0.5 & 24 & 12 \\
\hline & 0.6 & 24 & 13 \\
\hline & 0.7 & 24 & 15 \\
\hline Mean \pm SD & & & $12.50 \pm 2.08$ \\
\hline \multirow{5}{*}{ GPC (8) TM ${ }^{\circledR}$} & 0.4 & 24 & - \\
\hline & $0.5^{*}$ & 24 & - \\
\hline & 0.6 & 24 & 10 \\
\hline & 0.7 & 24 & 11 \\
\hline & 0.8 & 24 & 13 \\
\hline Mean \pm SD & & & $11.33 \pm 1.53$ \\
\hline \multirow[t]{5}{*}{$\mathrm{TH}^{4 \circledast}$} & 0.4 & 24 & - \\
\hline & $0.5 *$ & 24 & - \\
\hline & 0.6 & 24 & - \\
\hline & 0.7 & 24 & 10 \\
\hline & 0.8 & 24 & 11 \\
\hline Mean \pm SD & & & $10.50 \pm 0.71$ \\
\hline \multirow[t]{5}{*}{ Virocid ${ }^{\circledR}$} & 0.5 & 24 & - \\
\hline & $0.6^{*}$ & 24 & - \\
\hline & 0.7 & 24 & - \\
\hline & 0.8 & 24 & 10 \\
\hline & 0.9 & 24 & 11 \\
\hline & & & $10.50 \pm 0.71$ \\
\hline \multirow{5}{*}{ Lysol $^{\circledR}$} & 2.4 & 24 & - \\
\hline & $2.5^{*}$ & 24 & - \\
\hline & 2.6 & 24 & - \\
\hline & 2.7 & 24 & - \\
\hline & 2.8 & 24 & 10 \\
\hline Mean \pm SD & & & $10.00 \pm 0.00$ \\
\hline$P$ value & & & 0.459 \\
\hline Levels of significance & & & NS \\
\hline
\end{tabular}

NS means $(p>0.05)$

* Manufacturers recommendation.

(-) No zone of inhibition. 
Salmonellae isolated from internal organs of dead chickens

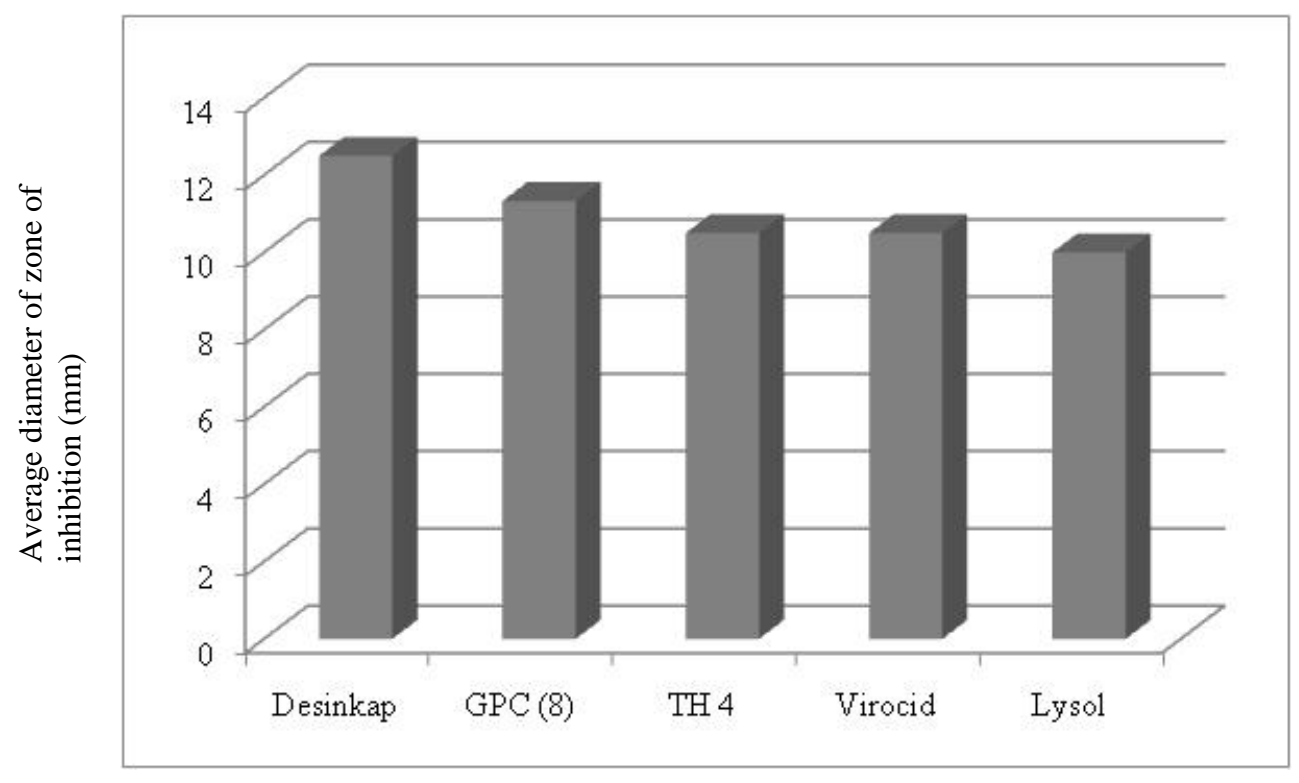

Time (24 hours)

Fig. 2. Comparison of average zone of inhibition values after 24 hours of incubation

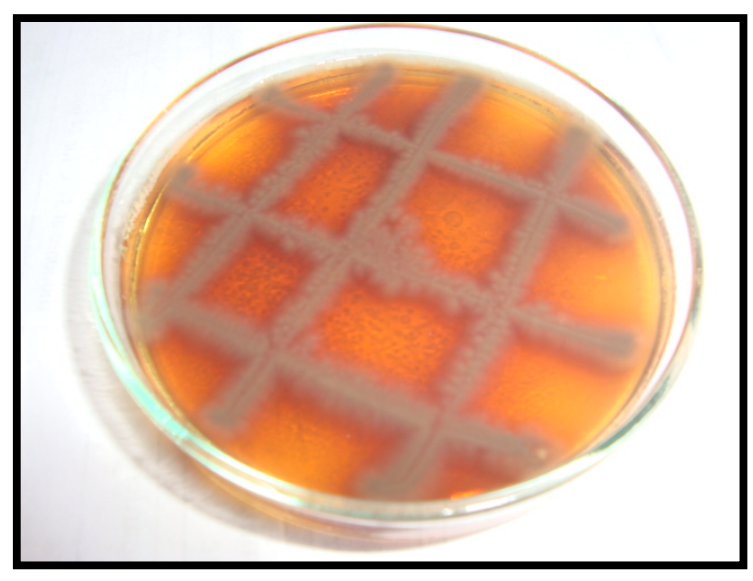

Plate 1. Growth of Salmonella in Salmonella- Shigella (SS) agar medium showing raised, rounded or circular, smooth, glistening, opaque, colorless, transparent or translucent colonies 


\section{N.A. Rumi and others}

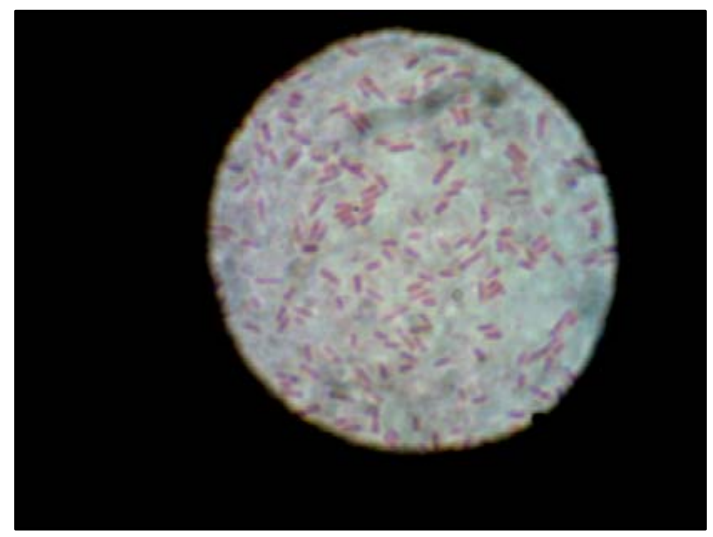

Plate 2. Salmonella spp. showing Gram negative small rods arranged singly or in pairs ( Gram’s staining)

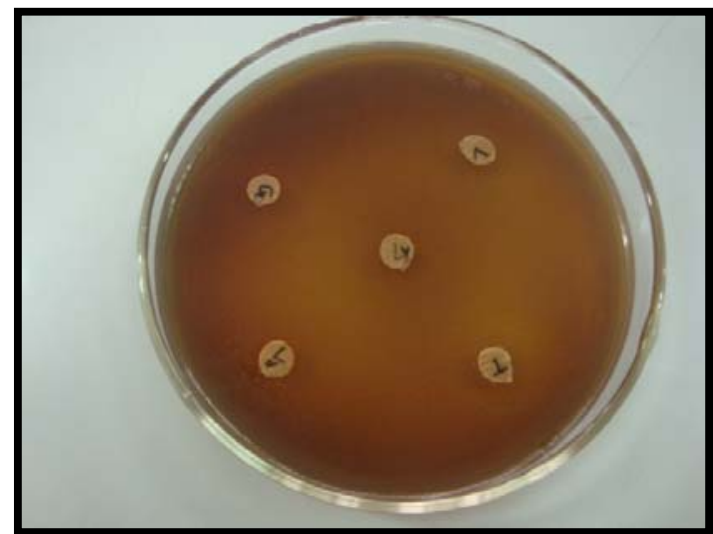

Plate 3. Lower concentration of disinfectants than the manufacturer's recommendation showing no zone of inhibition

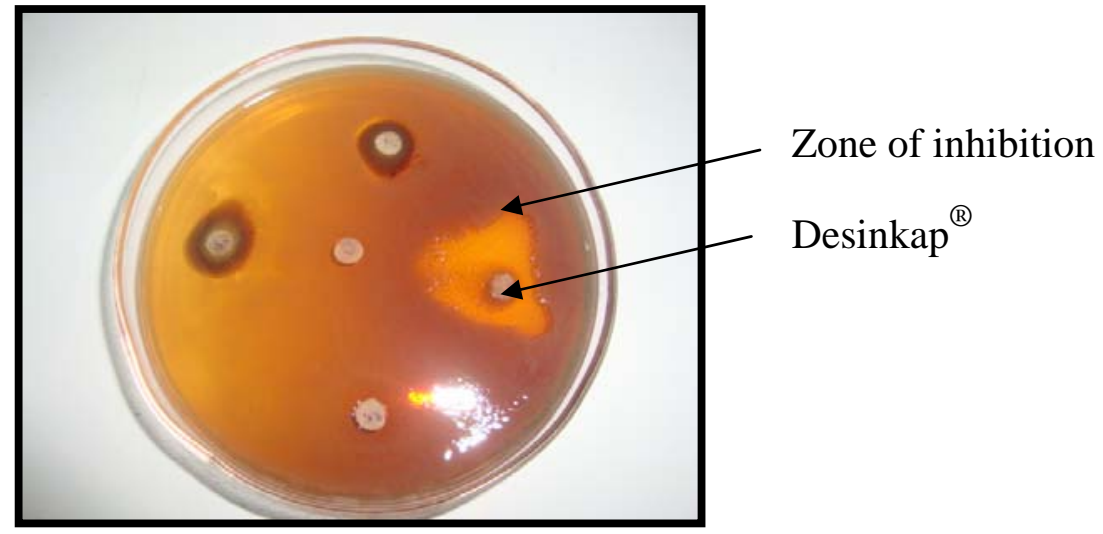

Plate 4. Concentration of disinfectants according to the manufacturer's recommendation showing zone of inhibition in case of Desinkap ${ }^{\circledR}$ 


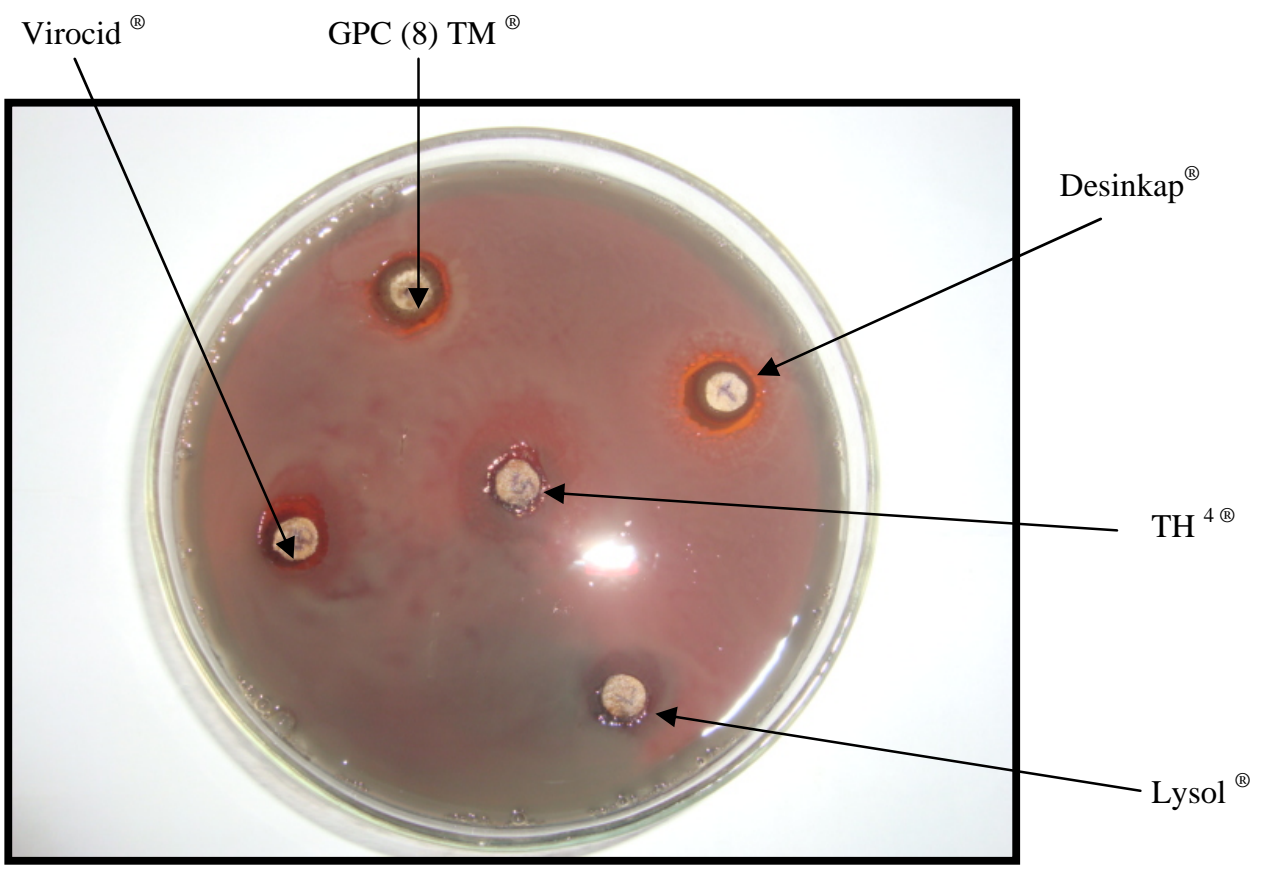

Plate 5. Higher concentration of disinfectants than the manufacturer's recommendation showing zone of inhibition

\section{REFERENCES}

1. Ahmed AKM, Islam MT, Haider MG and Hossain MM (2008). Seroprevalence and pathology of naturally infected Salmonellosis in poultry with isolation and identification of causal agents. Journal of Bangladesh Agricultural University 6(2): 327-334.

2. Begum F, Khan MSR, Choudhury KA, Rahman MM and Amin MM (1993). Studies on immune response of chickens to fowl typhoid vaccine. Bangladesh Journal of Microbiology. 10:51-56.

3. Buxton A and Fraser G (1977). Animal Microbiology. Vol. 1. Blackwell Scientific Publications, Oxford, London, Edinburg, Melbourne. pp. 103-115.

4. Freeman BA (1985). Burrows Textbook of Microbiology, twenty second Edition. W. B. Saunders Company, Philadelphia, London, Toronto, Mexico City, Rio de Janerio, Sydney, Tokeyo, pp. 464-475.

5. Gast IL K (1997). Salmonella infection, Diseases of Poultry, $10^{\text {th }}$ edn., P. 81.

6. Habib-ur-Rehman et al, (2004). Incidence and Gross pathology of Salmonella gallinarum Infection in chicken. Journal of Animal and Veterinary Advances 3 (3): 175-178.

7. Hofstad MS, John BH, Celnek BW, Reid WM and Yoder Jr. HW (1992). Diseases of Poultry. Eight Edition. Panima Education Book Agreny, New Delhi. Ind. p-73.

8. Hoque MM, Biswas HR and Rahman L (1992). Isolation, identification and production of Salmonella pullorum colored antigen in Bangladesh for the Rapid Whole Blood Test. Asian Australatian Journal of Animal Sciences. 10: 141-146.

9. Jones TC, Hunt RD and King NW (1997). Veterinary Pathology. $6^{\text {th }}$ edn. Williams and Wilkins Co., Baltimore, USA.

10. Kaura YK, Jagjit SR, Kidsbrestba X, Minakshi RC and Chaturvedi GC (1990). Salmonella gallinarum var. duishurg: An emerging biotype heavy mortality in poultry birds in northern India. Indian Journal of Animal Science. 60(2): 127-130.

11. Kleven SH and Yoder HW (1998). Mycoplasmosis. In: H, G. Purchase, L, H, Arp, C. H. Domermuth and J. E. Pearson (Eds). A Laboratory Manual for the Isolation and Identification of Avian Pathogens, 4hedn. American Association of Avian Pathologists, Kenett Square. pp. 74-80. 


\section{N.A. Rumi and others}

12. Kumar A and Kaushi RK (1988). Investigation of fowl typhoid in Haryana State. Indian Journal of Poultry Science. 23: 104-106.

13. Lee (2001). Comparative exclusion against Salmonella gallinarum in S. enteritidis infected chickens. Dissertation Abstracts International, 47(5): 1857.

14. Marin C, Hernandiz A and Lainez M (2009). Biofilm development capacity of Salmonella strains isolated in poultry risk factors and their resistance against disinfectants. Poultry Science. 88(2):424-31.

15. Merchant IA and Packer RA (1967). Veterinary Bacteriology and Virology. $7^{\text {th }}$ edn., The Iowa State University Press, Ames, Iowa, USA.

16. OIE (Office International Des Epizooties) (2000). Manual of standards for diagnostic tests and vaccines.

17. Pomeroy BS and Nagaraja KV. 1991. Fowl Typhoid. In: Diseases of Poultry, $9^{\text {th }}$ ed. B. W. Calnek. H. J. Barnes, C. W. Beard, W. M. Reid, and H. W. Yoder, Jr. Eds. Iowa State University Press, Ames, Iowa, pp. 87-99.

18. Rahman MM, Chowdhury TLMF, Rahn-mn MM and Hossain WIMA (1979). Surveillance of Salmonella and Escherichia organisms in poultry feed Bangladesh Veterinary Journal. 15(12): 59-62.

19. Sarker AJ (1976). The prevalence of avian disease in Bangladesh Agricultural University poultry Farm. Bangladesh Veterinary journal. 10(1-4): 672-678.

20. Sujatha K, Dhanalakshmi K and Rao AS (2003). Isolation and characterization of Salmonella gallinarum from chicken. Indian Veterinary Journal. 80(5):473-474. 